\title{
Article \\ Electroless Plating of High-Performance Composite Pd Membranes with EDTA-Free Bath
}

\author{
Jun-Yi Wang ${ }^{1}$, Yen-Hsun Chi ${ }^{2}$ and Jin-Hua Huang ${ }^{1, *}$ \\ 1 Department of Materials Science and Engineering, National Tsing Hua University, Hsinchu 30013, Taiwan; \\ jeff_ohno@hotmail.com \\ 2 Green Energy and Environment Research Laboratories, Industrial Technology Research Institute, \\ Hsinchu 31040, Taiwan; ansonchi@itri.org.tw \\ * Correspondence: jihhuang@mx.nthu.edu.tw
}

Citation: Wang, J.-Y.; Chi, Y.-H.; Huang, J.-H. Electroless Plating of High-Performance Composite Pd Membranes with EDTA-Free Bath. Materials 2021, 14, 4894. https:// doi.org/10.3390/ma14174894

Academic Editor: Renata Włodarczyk

Received: 25 July 2021

Accepted: 23 August 2021

Published: 27 August 2021

Publisher's Note: MDPI stays neutral with regard to jurisdictional claims in published maps and institutional affiliations.

Copyright: (c) 2021 by the authors. Licensee MDPI, Basel, Switzerland. This article is an open access article distributed under the terms and conditions of the Creative Commons Attribution (CC BY) license (https:// creativecommons.org/licenses/by/ $4.0 /)$.

\begin{abstract}
High-performance composite Pd membranes were successfully fabricated using electroless plating with an EDTA-free bath. The plating started with employing the one-time addition of hydrazine. In the experiment, the hydrazine concentrations and plating bath volumes were systematically varied to optimize the plating. The optimum composite $\mathrm{Pd}$ membrane tube showed high $\mathrm{H}_{2}$ permeance of $4.4 \times 10^{-3} \mathrm{~mol} / \mathrm{m}^{2} \mathrm{~s} \mathrm{~Pa} \mathrm{P}^{0.5}$ and high selectivity of $1.6 \times 10^{4}$, but poor cycling stability. Then, a method of sequential addition of the hydrazine from the high to low concentrations was employed. The resultant membrane, about $6 \mu \mathrm{m}$ thick, still exhibited a high selectivity of $6.8 \times 10^{4}$ as well as a much-improved plating yield and cycling stability level; this membrane outperformed the membrane made using the unmodified plating technique with the EDTA-contained bath. This result indicates the EDTA-free bath combined with the sequential addition of hydrazine is a simple, low-cost, yet effective method for preparing thin, dense composite Pd membranes featuring high hydrogen permeation flux and high thermal durability.
\end{abstract}

Keywords: palladium; electroless plating; hydrogen separation; membrane modification

\section{Introduction}

With the diminishing stock of fossil fuels and the growing concerns regarding environmental pollution problems, scientists have been making a great effort to search for renewable and clean energy resources. Because hydrogen fuel cells generate no pollutants and generally exhibit better efficiency than conventional internal combustion engines [1], hydrogen has been considered as one of the solutions for energy and environmental issues. Hydrogen can be obtained by cooperating water electrolysis with renewable power generation systems, such as solar and wind power [2,3]. It is attractive because no pollutants would be generated during hydrogen production, but the higher cost of this technique compared to hydrogen production from fossil fuels and biomass still limits its usage $[4,5]$. At present, the fossil fuel reforming method still comprises the majority of hydrogen production [6]. Because the cost of hydrogen production via fossil fuels heavily relies on the fuel price, areas with low fuel costs, such as the Middle East and North America, have much lower hydrogen production costs. Extracting hydrogen from fossil fuels and biomass will inevitably generate by-product gas, such as carbon monoxide, carbon dioxide, and methane. Notably, carbon monoxide would poison fuel cells and degrade cell performance; thus, further purification of as-produced hydrogen is needed. The development of effective methods of hydrogen separation, therefore, has raised considerable interests within academia and industry [7].

Among the various types of hydrogen separating inorganic membranes, metal membranes made of palladium (Pd), and its alloys are the most widely studied due to their unique permselectivity to hydrogen [8,9]. Theoretically, ultra-pure hydrogen can be obtained from defect-free $\mathrm{Pd}$. However, in order to lower the cost of $\mathrm{Pd}$ and shorten the 
diffusion length (thus resulting in higher $\mathrm{H}_{2}$ permeance), many researchers have focused on the fabrication of composite Pd-based membranes, which generally consist of a Pdbased thin film with a thickness of several micrometers on porous substrates, such as porous stainless steel (PSS) and microporous glass tubes [10,11]. Several methods have been developed to fabricate the composite Pd-based membranes, including sputtering, chemical vapor deposition, electroplating, and electroless plating [12-17]. Among these methods, electroless plating is attractive because it uses only simple equipment that is easy to scale up.

Electroless plating is a well-developed technique that is widely used to prepare dense Pd membranes on porous substrates. Procedures of electroless plating in recent research are normally similar. Indeed, recent research on Pd membrane preparation mostly focuses on other aspects, especially the intermediate layer between the Pd and the substrate [18-20]. Few researchers put effort into plating bath modification because it is a fairly mature technique. Conventional plating baths used in electroless plating contain a chelating agent, EDTA (ethylenediaminetetraacetic acid). to control the plating rate and prevent the whole plating stage from bulk decomposition. However, a trace of the EDTA tends to remain in the as-fabricated membranes. Volpe et al. [21], for example, detected an EDTA signal in an EDTA-contained plating, bath-derived Pd membrane by using Fourier transform infrared spectroscopy. Roa et al. [22] also found EDTA residue through thermogravimetric analysis. EDS analysis can also point out carbon impurities inside the Pd membrane derived from EDTA-contained bath [23].

Unfortunately, incorporated EDTA in membranes not only could serve as stress that produces defects, but it could also evolve into carbon monoxide at high temperatures and cause degradation of the membrane performance thereafter. In this regard, several researchers have successfully fabricated palladium membranes with an EDTA-free bath. Gade et al. [24], for example, fabricated unsupported Pd membranes from an EDTA-free bath at $50{ }^{\circ} \mathrm{C}$. However, the relatively high plating temperature of $50{ }^{\circ} \mathrm{C}$ made the plating unstable so that the plating stage could last only $20 \mathrm{~min}$. As a result, eight or more plating stages were needed to achieve a visibly pinhole-free membrane. Moreover, the repeated short plating cycles resulted in low-yield Pd membranes and made the fabrication costly. Ryi et al. [25] fabricated Pd membranes on porous Hastelloy discs with an EDTA-free bath at a lower working temperature of $25{ }^{\circ} \mathrm{C}$. Nevertheless, the relatively small surface area of Hastelloy discs would limit its gas flow in practical use. Thoen et al. [26] fabricated Pd-Cu membranes onto alumina tubes with an EDTA-free bath, and the results showed that the nitrogen flux drastically increased after six days of permeation testing. Although carbon contamination was absent, the use of EDTA-free baths in electroless plating still needs further investigation for practical use. Based on the aforementioned references, plating without EDTA would be relatively tough to execute. Parameters, such as plating time or plating temperature, should be tuned and monitored to achieve a high-quality $\mathrm{Pd}$ membrane.

In this work, thin Pd membranes were fabricated on the PSS tubes using electroless plating with an EDTA-free bath, as well. The PSS tubes were chosen to be the substrate materials because of the concern about practicality and cost reduction. Initially, hydrazine concentration and plating bath volume were varied. For each plating condition (a set of hydrazine concentration and plating bath volume), the tube would undergo two identical plating stages. Performances of different tubes were then discussed in detail to find the optimized plating parameters. However, all as-fabricated membranes showed poor thermal stability. To solve for this, the sequential addition of hydrazine with concentrations from high to low was introduced. The resultant membrane, prepared using the EDTA-free bath and sequential addition of hydrazine. showed a competitive permselective performance, high plating yield, and much-improved reliability. 


\section{Materials and Methods}

\subsection{Membrane Preparation}

Hollow PSS tubes, as supporting substrates for loading Pd membranes, were purchased from Pall Corporation (New York, NY, USA). The PSS tubes had an outer diameter of $11.8 \mathrm{~mm}$, a wall thickness of $0.89 \mathrm{~mm}$, and a length of $150 \mathrm{~mm}$. To fit the gas flux measuring module, a nonporous stainless-steel tube was welded to one end of each PSS tube, and a nonporous stainless steel cap was welded to the opposite end. Then, the welded PSS tubes were ultrasonicated sequentially in alkaline, isopropyl alcohol, and deionized water to remove surface contaminants, such as oil, dirt, and grease. Finally, the PSS tubes were dipped in an isopropanol bath and then dried at $393 \mathrm{~K}$ overnight.

The commercial PSS tubes usually display high surface roughness with large and on-uniform pores, which could lead to cracks, pinholes, and defects over the surface of as-fabricated membranes. Therefore, a two-step surface modification was undertaken to reduce the pore size of the PSS surface. Details of the surface modification procedures have been described in our previous studies [16,17]. In brief, $10 \mu \mathrm{m}, 99.5 \%$ alumina $\left(\mathrm{Al}_{2} \mathrm{O}_{3}\right)$ particles purchased from Merck (Burlington, MA, USA) were first used to fill the large pores of the PSS substrate surface. Then, the $\mathrm{Al}_{2} \mathrm{O}_{3} /$ PSS tubes were immersed in solutions with a lithium-aluminide ingot (80/20 wt\%) intermetallic compound (Li-Al IMC) $(99.9 \%$, UMAT, Hsinchu, Taiwan) to ensure the growth of the Li-Al layered double hydroxide $(\mathrm{LDH})$ layer and further reduce the pore size. Both the $\mathrm{Al}_{2} \mathrm{O}_{3}$ particles and the $\mathrm{LDH}$ layer not only smoothed the surfaces of the PSS tubes, but also served together as the diffusion barrier between the PSS tube and Pd membrane.

After surface modification with $\mathrm{Al}_{2} \mathrm{O}_{3}$ and $\mathrm{LDH}$, a surface activation process was carried out to ensure better adhesion of the Pd during the plating stage. Each $\mathrm{LDH}-\mathrm{Al}_{2} \mathrm{O}_{3}-$ modified PSS tube was subjected to a surface activation process, which was carried out by alternately immersing the PSS tubes into the $\mathrm{SnCl}_{2}$ (99.7\%, Macron, Radnor, PA, USA) and $\mathrm{PdCl}_{2}$ (99.99\%, UR, New Taipei, Taiwan) solutions several times. After activation, the PSS tube surface was expected to be fully covered with a Pd nuclei layer.

Pd membranes were deposited onto the PSS tubes at $30^{\circ} \mathrm{C}$ with an EDTA-free bath. The EDTA-free bath was composed of $\mathrm{PdCl}_{2}, \mathrm{HCl}$, and $\mathrm{NH}_{4} \mathrm{OH}$, and was stirred well to form a fine mixture before electroless plating. The detailed composition of the EDTA-free bath is described in Table 1. During plating, the PSS tubes were immersed into glass tubes with an EDTA-free bath. Plating temperature was controlled by a larger water tank. Throughout each of the plating stages, tubes would be rotated at a fixed speed to achieve a smoother membrane. After that, the plating with an EDTA-free bath was first conducted by undertaking two identical plating stages; each stage lasted $90 \mathrm{~min}$ and included the one-time addition of hydrazine $\left(\mathrm{N}_{2} \mathrm{H}_{4}\right)$, as depicted in Figure 1a. Five concentrations of hydrazine $(4.5,6.75,9,13.5$, and $18 \mathrm{mM})$ and three volumes of plating bath $(120,180$, and $240 \mathrm{~mL}$ ) were systematically varied to optimize the plating. Then, the approach of using the one-time addition of the hydrazine was changed to sequential addition, wherein hydrazine was sequentially added-in concentrations from the high to low-to the same plating bath, as demonstrated in Figure 1b. The membranes fabricated from the EDTA-free bath that utilized the sequential addition of hydrazine have shown excellent $\mathrm{H}_{2}$ permselectivity and thermal durability.

Table 1. Compositions of EDTA-free baths for electroless Pd plating.

\begin{tabular}{cc}
\hline Components & Amount \\
\hline $\mathrm{PdCl}_{2}$ & $3.2 \mathrm{~g} / \mathrm{L}$ \\
$\mathrm{HCl}$ & $4 \mathrm{~mL} / \mathrm{L}$ \\
$\mathrm{NH}_{4} \mathrm{OH}$ & $320 \mathrm{~mL} / \mathrm{L}$ \\
\hline
\end{tabular}




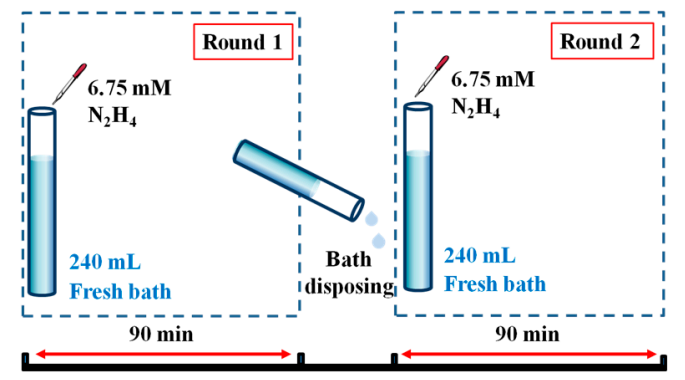

(a)

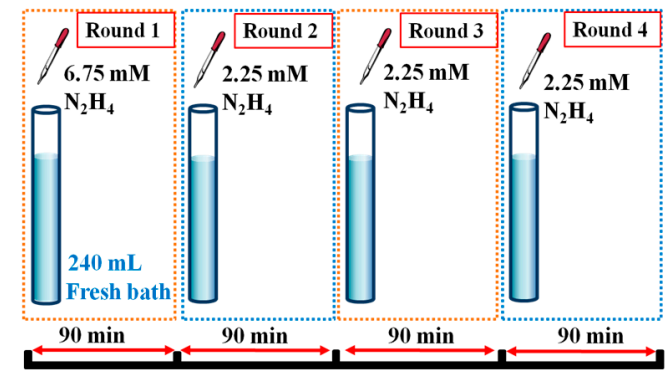

(b)

Figure 1. Schematics of the two approaches of hydrazine addition employed in this work: (a) onetime addition; (b) sequential addition.

\subsection{Characterization}

The hydrogen permeance and nitrogen leakage rate were measured with a homemade gas flux measuring module, as schematically shown in Figure 2. The temperature was initially ramped to $400{ }^{\circ} \mathrm{C}$ at a rate of $1{ }^{\circ} \mathrm{C} / \mathrm{min}$ with nitrogen flowing, and then it was kept at $400{ }^{\circ} \mathrm{C}$ for $5 \mathrm{~h}$ with flowing hydrogen to undergo surface reduction. After that, both hydrogen and nitrogen fluxes were measured at 1-4 bar pressure differences. Cycling stability tests, including temperature rising and descending on a daily basis, were carried out afterward to verify the thermal durability of the membranes. Permeation measurements were undertaken daily to realize the rate of performance degradation. Both gases used in the permeation test had a purity level of $99.99 \%$ or higher. Moreover, all permeation tests were conducted in a single-gas situation; the results would not be typical of a real case of mix-gas. The morphology of as-prepared Pd membranes was obtained through scanning electron microscopy (SEM, JSM-6500F, JEOL, Tokyo, Japan). The tubes for SEM analyses were cut into small pieces and embedded in epoxy. The embedded tubes were then ground and polished to obtain clear SEM images. The membrane thickness measurements were estimated based on the cross-sectional SEM micrographs and a weight-gain method, which showed consistent results.

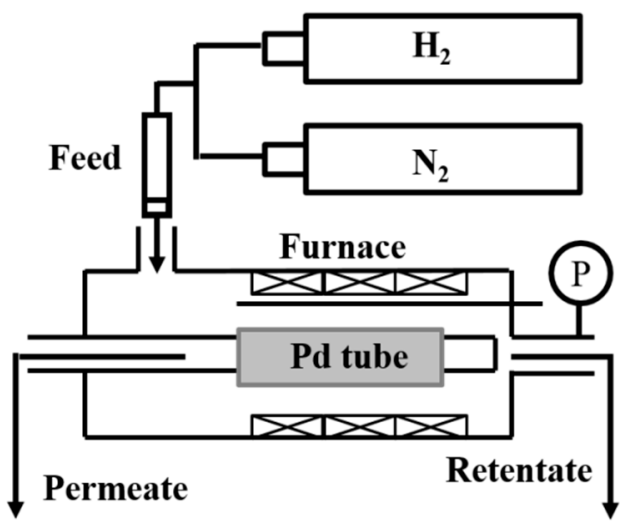

Figure 2. The homemade permeation-measuring module for pure hydrogen and nitrogen permeation measurements.

\section{Results and Discussion}

In this work, the palladium film during electroless plating with an EDTA-free bath glowed according to the following reaction:

$$
2 \mathrm{Pd}^{2+}+\mathrm{N}_{2} \mathrm{H}_{4}+4 \mathrm{OH}^{-} \rightarrow 2 \mathrm{Pd}+\mathrm{N}_{2}+4 \mathrm{H}_{2} \mathrm{O}
$$

As Equation (1) shows, the $\mathrm{N}_{2} \mathrm{H}_{4}$ concentration influences the reaction rates of the as-fabricated Pd films. Likewise, the volume of the plating bath determines the Pd content 
and film thickness, thereby strongly influencing the morphology of Pd membranes. Initially, $\mathrm{N}_{2} \mathrm{H}_{4}$ was added in the bath using the one-time addition approach, as depicted in Figure 1a. In the experiment, the two parameters, namely the volume of the plating bath and the concentration of $\mathrm{N}_{2} \mathrm{H}_{4}$, were systematically varied to optimize the EDTA-free bath. The surface area of the PSS supports in this study was about $61 \mathrm{~cm}^{2}$, and the volumes of plating bath were chosen to be 120,180 , and $240 \mathrm{~mL}$, thus yielding the corresponding volumeto-surface area ratios of approximately 2, 3, and 4, respectively. Table 2 summarizes the properties and performances of as-fabricated Pd membranes. Be aware that the $\mathrm{H}_{2}$ permeance in Table 2 was obtained by plotting the $\mathrm{H}_{2}$ flux against the difference of the square root of pressure. The coefficient of determination, or $\mathrm{R}^{2}$, is greater than 0.999 for all membranes listed in the table, which means the $\mathrm{H}_{2}$ permeation in this study is basically under the diffusion-controlled mechanism.

Table 2. Properties and performances of various membranes prepared using different bath volumes and hydrazine concentrations.

\begin{tabular}{|c|c|c|c|c|c|c|}
\hline $\begin{array}{l}\mathrm{N}_{2} \mathrm{H}_{4} \text { Conc. } \\
(\mathrm{mM})\end{array}$ & $\begin{array}{l}\text { Bath Volume } \\
(\mathrm{mL})\end{array}$ & $\begin{array}{c}\text { Plating Yield a } \\
\text { (\%) }\end{array}$ & $\begin{array}{c}\text { Pd Thickness } \\
(\mu \mathrm{m})\end{array}$ & $\begin{array}{l}\mathrm{H}_{2} \text { Permeance } \\
\left(\mathrm{mol} / \mathrm{m}^{2} \mathrm{~s} \mathrm{~Pa}^{0.5}\right)\end{array}$ & $\begin{array}{l}\mathrm{N}_{2} \text { Flux } \\
\left(\mathrm{mol} / \mathrm{m}^{2} \mathrm{~s}\right)\end{array}$ & $\begin{array}{c}\text { Selectivity }^{\mathrm{d}} \\
{\left[\mathrm{H}_{2} / \mathrm{N}_{2}\right]}\end{array}$ \\
\hline 4.5 & 120 & 33 & 2.2 & $\#^{\mathrm{e}}$ & $9.6 \times 10^{-1}$ & $\#^{\mathrm{e}}$ \\
\hline 4.5 & 180 & 31 & 3.0 & $\#^{\mathrm{e}}$ & $2.0 \times 10^{-3}$ & $\#^{\mathrm{e}}$ \\
\hline 4.5 & 240 & 33 & 4.3 & $5.9 \times 10^{-3}$ & $8.5 \times 10^{-5}$ & $1.1 \times 10^{2}$ \\
\hline 6.75 & 120 & 55 & 3.6 & $6.8 \times 10^{-3}$ & $1.9 \times 10^{-3}$ & $1.7 \times 10^{2}$ \\
\hline 6.75 & 180 & 51 & 5.0 & $4.4 \times 10^{-3}$ & $6.0 \times 10^{-6}$ & $1.6 \times 10^{4}$ \\
\hline 6.75 & 240 & 46 & 6.0 & $3.4 \times 10^{-3}$ & $1.3 \times 10^{-5}$ & $5.9 \times 10^{3}$ \\
\hline 9 & 120 & 86 & 5.5 & $3.4 \times 10^{-3}$ & $5.8 \times 10^{-5}$ & $8.6 \times 10^{2}$ \\
\hline 9 & 180 & 60 & 5.8 & $3.1 \times 10^{-3}$ & $9.6 \times 10^{-6}$ & $5.0 \times 10^{3}$ \\
\hline 9 & 240 & 47 & 6.1 & $3.3 \times 10^{-3}$ & $7.2 \times 10^{-6}$ & $8.1 \times 10^{3}$ \\
\hline 13.5 & 120 & 93 & 6.0 & $3.3 \times 10^{-3}$ & $2.2 \times 10^{-5}$ & $1.3 \times 10^{3}$ \\
\hline 13.5 & 180 & 66 & 6.4 & $2.9 \times 10^{-3}$ & $2.4 \times 10^{-6}$ & $1.8 \times 10^{4}$ \\
\hline 13.5 & 240 & 56 & 7.2 & $2.6 \times 10^{-3}$ & $4.8 \times 10^{-6}$ & $1.1 \times 10^{4}$ \\
\hline 18 & 120 & 96 & 6.2 & $2.8 \times 10^{-3}$ & $1.7 \times 10^{-3}$ & 83 \\
\hline 18 & 180 & 84 & 8.2 & $2.2 \times 10^{-3}$ & $1.2 \times 10^{-4}$ & $3.0 \times 10^{2}$ \\
\hline 18 & 240 & 68 & 8.9 & $2.0 \times 10^{-3}$ & $3.8 \times 10^{-5}$ & $1.5 \times 10^{3}$ \\
\hline
\end{tabular}

${ }^{a}$ Ratio of estimated $\mathrm{Pd}^{2+}$ usage (derived from the weight gain after deposition) and the original $\mathrm{Pd}^{2+}$ in the bath. ${ }^{\mathrm{b}}$ Measured at $400{ }^{\circ} \mathrm{C}$.

${ }^{c}$ Measured at room temperature and 1-bar pressure difference prior to $\mathrm{H}_{2}$ flux measurements. ${ }^{\mathrm{d}}$ Defined as the ratio of the $\mathrm{H}_{2}$ flux to the

$\mathrm{N}_{2}$ flux at $400{ }^{\circ} \mathrm{C}$ and 4-bar pressure difference. ${ }^{e}$ Did not undergo the permeance measurements due to the large $\mathrm{N}_{2}$ leakage fluxes.

It is obvious that for the three concentrations of $\mathrm{N}_{2} \mathrm{H}_{4}$ investigated, the membrane thickness increased as the bath volume increased. This result is reasonable because a higher volume of bath, which corresponds to a higher content of palladium ions, could sustain a relatively stable reaction rate for a longer plating time. However, the hydrogen permeance decreased as the bath volume increased, which could be attributed to the increasing thickness of the membrane, as $\mathrm{H}_{2}$ permeation has been previously proved to be a diffusion-controlled process. Figure 3 shows the surface morphologies of the $\mathrm{Pd}$ membranes fabricated using the same $6.75 \mathrm{mM}$ of the $\mathrm{N}_{2} \mathrm{H}_{4}$ addition but different bath volumes of 120 and $240 \mathrm{~mL}$. For the membrane fabricated from the $120 \mathrm{~mL}$ bath (shown in Figure 3a), a relatively rough surface was observed. However, the vertical, sheet-like structure of the LDH morphology could still be distinguished, revealing that the $\mathrm{Pd}$ membrane in Figure 3a is relatively thin and thorough coverage of the Pd is not yet formed. The high $\mathrm{N}_{2}$ flux and low $\mathrm{H}_{2} / \mathrm{N}_{2}$ selectivity measured from this sample confirm the observation. On the contrary, the membrane obtained from the $240 \mathrm{~mL}$ plating bath (shown in Figure 3b), shows a much smoother surface without evident pinholes. This morphology difference could explain why the latter one has a much lower $\mathrm{N}_{2}$ leaking flux. 

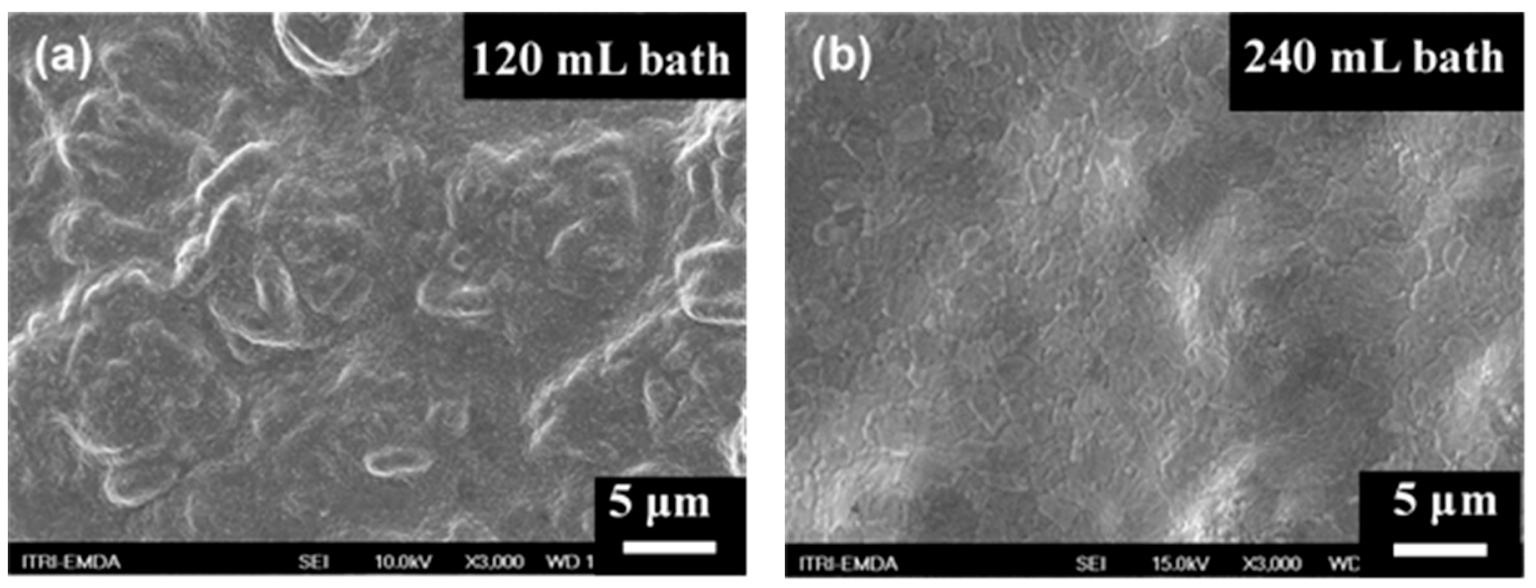

Figure 3. SEM plane view images of the membranes prepared using the same $6.75 \mathrm{mM}$ concentration of the hydrazine addition but different volumes of bath: (a) $120 \mathrm{~mL}$; (b) $240 \mathrm{~mL}$.

Mardilovich et al. have shown that there is a minimum Pd film thickness required to form a dense membrane on a porous substrate using electroless plating, which is about three times the size of the largest pore of the porous substrate [27]. In this study, the threshold thickness was found around approximately 3.5-4 $\mu \mathrm{m}$. It is relatively tough to form a dense membrane via the $120 \mathrm{~mL}$ bath because of a lower content of $\mathrm{Pd}^{2+}$ in the plating bath.

As Table 2 states, both the bath volume and the $\mathrm{N}_{2} \mathrm{H}_{4}$ concentration can influence the resultant thickness of the Pd. Unlike bath volume, an increased concentration of $\mathrm{N}_{2} \mathrm{H}_{4}$ can raise the reaction rate and hence increase the resultant thickness. The calculated plating yield in Table 2 also confirms this. According to Yeung et al., the plating rate of the $\mathrm{N}_{2} \mathrm{H}_{4}$-based baths should be correlated with the concentration of $\mathrm{N}_{2} \mathrm{H}_{4}$ [28]. Furthermore, Yeung et al. also pointed out the larger grains of palladium could be obtained with higher concentrations of the $\mathrm{N}_{2} \mathrm{H}_{4}$ addition.

In this study, five different concentrations of the $\mathrm{N}_{2} \mathrm{H}_{4}$ addition, ranging from 4.5 to $18 \mathrm{mM}$, were applied. For the lowest concentration (i.e., $4.5 \mathrm{mM}$ ) of the $\mathrm{N}_{2} \mathrm{H}_{4}$ addition, the nitrogen leakage rates of the as-fabricated membranes are, generally, quite high. This can be ascribed to the relatively thin, porous membranes obtained. Similarly, the membranes fabricated from the highest concentration (i.e., $18 \mathrm{mM}$ ) of the $\mathrm{N}_{2} \mathrm{H}_{4}$ addition also show relatively higher nitrogen leakage rates, although the thickness levels are far beyond $5 \mu \mathrm{m}$, which implies these thick membranes are not as dense as expected. The plating baths of these membranes were found to turn murky during plating. Moreover, several large particles, in the range of several millimeters, could be visually observed on the surface of the membranes after plating. Both phenomena indicate a bulk decomposition of $\mathrm{Pd}$ during plating for the case of the $18 \mathrm{mM} \mathrm{N}_{2} \mathrm{H}_{4}$ addition. Consequently, the concentration of an $\mathrm{N}_{2} \mathrm{H}_{4}$ addition should be within the range of 6.75 to $13.5 \mathrm{mM}$ to achieve a palladium membrane with better performance.

To examine whether the as-made membranes are practical in use, the membranes made from the 6.75 and $9 \mathrm{mM} \mathrm{N}_{2} \mathrm{H}_{4}$ additions (with the same bath volume of $180 \mathrm{~mL}$ ) were selectively chosen to undergo the cycling stability test. These results are shown in Figure 4. Although the two membranes exhibited different selectivity values $\left(1.6 \times 10^{4}\right.$ and $5.0 \times 10^{3}$, respectively) in the beginning, they deteriorated afterward, with selectivity steadily dropping to about 2000. Since the $\mathrm{N}_{2}$ flux of both membranes increased steadily throughout the test, the membranes are expected to fail during longer operation times. Moreover, the plating yield of qualified membranes was relatively low. To solve these two problems, we induced a multi-step method of plating, which consisted of stages with plating rates from high to low, as demonstrated in Figure $1 \mathrm{~b}$. The arrangement of the plating rate was achieved by controlling the concentrations of hydrazine. Based on the research of Felix's group, pore-clogging is more easily achieved through a faster plating 
rate, which can be schematically illustrated in Figure 5 [29]. In this experiment, a high concentration of the hydrazine addition in the first plating stage was used to ensure that pore-clogging took place in a relatively short amount of time. This could ensure most of the Pd deposits were on the surface instead of being in the pore of the PSS tube. After the fast-plating stage, three slow plating stages, with lower concentrations of the hydrazine addition, were employed to fabricate a dense membrane with fewer defects and a greater plating yield.

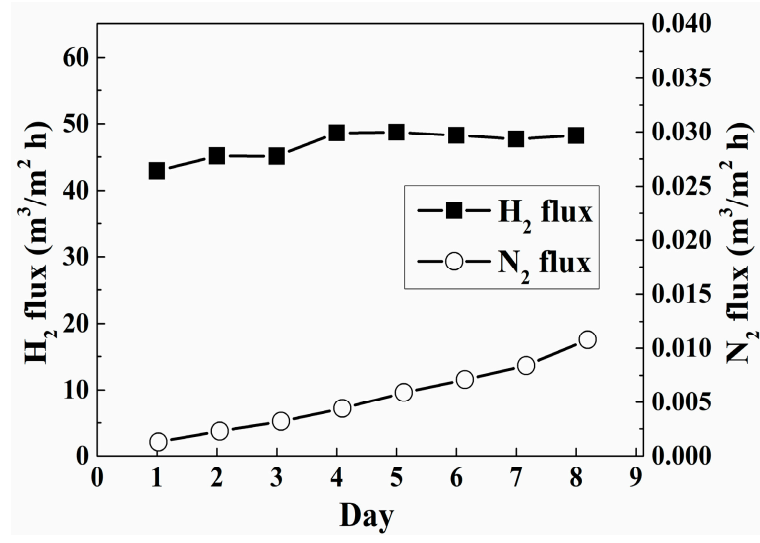

(a)

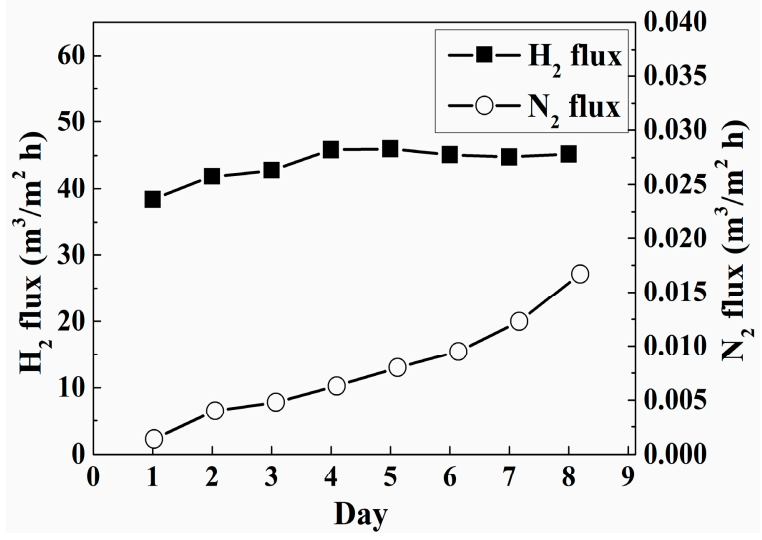

(b)

Figure 4. Thermal stability tests of the membranes were prepared using the same bath volume of $180 \mathrm{~mL}$ but different concentrations of hydrazine: (a) $6.75 \mathrm{mM}$; (b) $9 \mathrm{mM}$.

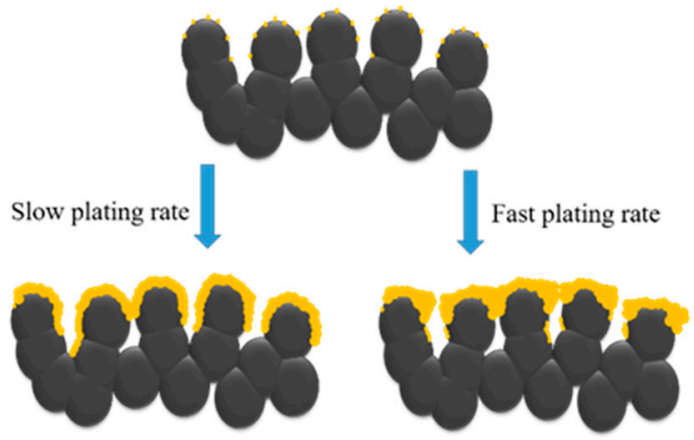

Figure 5. Schematics illustrating the stacking behaviors of Pd with slow and fast plating rates.

Table 3 compares the properties and performances of the Pd membranes that were prepared using the two different approaches of $\mathrm{N}_{2} \mathrm{H}_{4}$ addition with EDTA-free baths. As mentioned previously, a threshold thickness of the Pd film is required to obtain a dense, defect-free membrane. Therefore, changing the plating bath was inevitable, and the plating yield was reduced accordingly for the one-time addition approach. On the contrary, by using the new approach of sequential addition of the $\mathrm{N}_{2} \mathrm{H}_{4}$, changing the bath was no longer needed and the plating yield could be greatly increased. In Table 3 , the membrane prepared through sequential addition exhibited a high $\mathrm{H}_{2} / \mathrm{N}_{2}$ selectivity and a drastically enhanced plating yield, though with slightly reduced hydrogen permeance. The cycling stability test of the membrane, prepared using sequential addition, was also undertaken. As can be seen in Figure 6, the $\mathrm{H}_{2}$ and $\mathrm{N}_{2}$ fluxes varied similarly with the daily test. The two fluxes first increased soundly and then increased slowly as time passed, indicating an almost stable selectivity of the membrane. The result indicates that the as-fabricated membrane can work for a longer time, which means the new approach for the hydrazine addition is more practical in use. 
Table 3. Compositions of EDTA-free baths for electroless Pd plating.

\begin{tabular}{cccccc}
\hline $\mathbf{N}_{\mathbf{2}} \mathbf{H}_{\mathbf{4}}$ Addition & Thickness & Yield & $\mathbf{H}_{\mathbf{2}}$ Permeance & $\mathbf{N}_{\mathbf{2}}$ Flux $^{\mathbf{c}}$ & Selectivity $^{\mathbf{c}}$ \\
\hline & $\boldsymbol{\mu} \mathbf{m}$ & $\mathbf{\%}$ & $\mathbf{m o l} / \mathbf{m}^{\mathbf{2}} \mathbf{s ~ P a}^{\mathbf{0 . 5}}$ & ${\mathbf{~ m o l} / \mathbf{m}^{\mathbf{2}} \mathbf{s}}$ & $\mathbf{H}_{\mathbf{2}} / \mathbf{N}_{\mathbf{2}}$ \\
\hline One-Time $^{\mathrm{a}}$ & 6.00 & 46 & $5.9 \times 10^{-3}$ & $1.3 \times 10^{-5}$ & $5.9 \times 10^{3}$ \\
Sequential $^{\mathrm{b}}$ & 6.00 & 93 & $3.0 \times 10^{-3}$ & $1.2 \times 10^{-6}$ & $6.8 \times 10^{4}$ \\
\hline
\end{tabular}

a Based on $\left[\mathrm{N}_{2} \mathrm{H}_{4}\right]=6.75 \mathrm{mM}$ and plating bath volume $=240 \mathrm{~mL}$, as schematically shown in Figure 1a. ${ }^{\mathrm{b}}$ Based on $\left[\mathrm{N}_{2} \mathrm{H}_{4}\right]=6.75,2.25,2.25$, and $2.25 \mathrm{mM}$ and plating bath volume $=240 \mathrm{~mL}$, as schematically shown in Figure $1 \mathrm{~b}$. ${ }^{c}$ The measurement conditions are the same as those in Table 1.

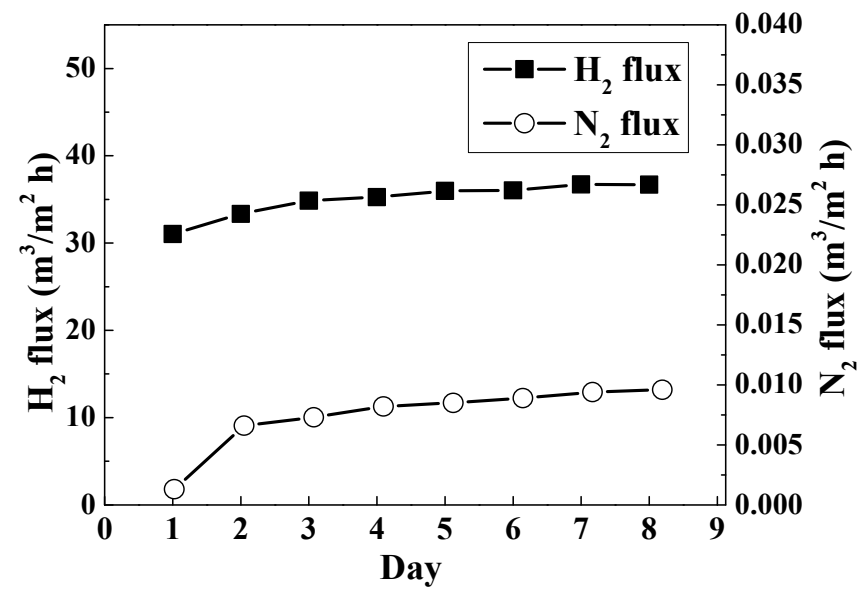

Figure 6. Thermal stability test of the Pd membrane prepared using the EDTA-free bath and the sequential addition of hydrazine.

\section{Conclusions}

In conclusion, we have presented a systematic study on the electroless plating of $\mathrm{Pd}$ membranes on porous stainless-steel tubes using an EDTA-free bath. Initially, the plating was conducted by varying the bath volume and $\mathrm{N}_{2} \mathrm{H}_{4}$ concentration using the one-time addition of $\mathrm{N}_{2} \mathrm{H}_{4}$. We found that a bath volume of 180 to $240 \mathrm{~mL}$ and an $\mathrm{N}_{2} \mathrm{H}_{4}$ concentration of 6.75 to $13.5 \mathrm{mM}$ were appropriate to support the formation of $\mathrm{Pd}$ membranes with better performances. With a small volume of bath, the Pd film thickness would be too small to form a dense membrane; however, with a large volume of bath, the hydrogen permeance of the membrane would be greatly decreased because of the increasing thickness. On the other hand, a low concentration of the $\mathrm{N}_{2} \mathrm{H}_{4}$ addition would result in a membrane with large nitrogen flux owing to the small thickness; conversely, a high concentration of the hydrazine addition would cause bath decomposition, leading to a membrane with large nitrogen flux, too. The optimum composite membrane tube was obtained from the $180 \mathrm{~mL}$ bath and $6.75 \mathrm{mM}$ hydrazine addition, which exhibited $\mathrm{H}_{2}$ permeance of $4.4 \times 10^{-3} \mathrm{~mol} / \mathrm{m}^{2} \mathrm{~s} \mathrm{~Pa}{ }^{0.5}$ and selectivity of $1.6 \times 10^{4}$. However, all as-fabricated membrane tubes degraded quickly upon the temperature cycling test, which limited their practical use. An arranged concentration sequence of $\mathrm{N}_{2} \mathrm{H}_{4}$ additions from high to low was then introduced. The fast-plating rate in the first stage ensured poreclogging, while the slow plating rate afterward helped reduce the defects to the membrane. The resultant membrane thus showed much better stability and higher plating yield. The deposition method, the EDTA-free bath together with the sequential addition of $\mathrm{N}_{2} \mathrm{H}_{4}$, is simple and low-cost, yet effective, which made it a competitive technique in terms of practical use.

Author Contributions: Conceptualization, J.-Y.W. and Y.-H.C.; methodology, J.-Y.W. and Y.-H.C.; investigation, J.-Y.W., Y.-H.C.; data curation, J.-Y.W.; writing—original draft preparation, J.-Y.W.; writing-review and editing, J.-Y.W. and J.-H.H.; supervision, Y.-H.C. and J.-H.H.; funding acquisition, Y.-H.C. All authors have read and agreed to the published version of the manuscript. 
Funding: This research received no external funding.

Institutional Review Board Statement: Not applicable.

Informed Consent Statement: Not applicable.

Data Availability Statement: Data are available on demand by asking the corresponding author.

Acknowledgments: The author would like to thank the Industrial Technology Research Institute for experimental assistance. The author also thanks the National Science Council of Taiwan for Ph.D. funding.

Conflicts of Interest: The authors declare no competing financial interest.

\section{References}

1. Solomon, B.D.; Banerjee, A. A global survey of hydrogen energy research, development and policy. Energy Policy 2006, 34, 781-792. [CrossRef]

2. Kalbasi, R.; Jahangiri, M.; Tahmasebi, A. Comprehensive Investigation of Solar-Based Hydrogen and Electricity Production in Iran. Int. J. Photoenery 2021, 2021, 6627491. [CrossRef]

3. Calado, G.; Castro, R. Hydrogen production from offshore wind parks: Current situation and future perspectives. Appl. Sci. 2021, 11, 5561. [CrossRef]

4. El-Emam, R.S.; Ozcan, H. Comprehensive review on the techno-economics of sustainable large-scale clean hydrogen production. J. Clean. Prod. 2019, 220, 593-609. [CrossRef]

5. Wang, M.; Wang, G.; Sun, Z.; Zhang, Y.; Xu, D. Review of renewable energy-based hydrogen production processes for sustainable energy innovation. Glob. Energy Interconnect 2019, 2, 436-443. [CrossRef]

6. International Energy Agency. Available online: https://www.iea.org/reports/the-future-of-hydrogen (accessed on 22 August 2021).

7. Du, Z.; Liu, C.; Zhai, J.; Guo, X.; Xiong, Y.; Su, W.; He, G. A Review of Hydrogen Purification Technologies for Fuel Cell Vehicles. Catalysts 2021, 11, 393. [CrossRef]

8. Shu, J.; Grandjean, B.P.A.; Vanneste, A.; Kaliaguine, S. Catalytic palladium-based membrane reactors: A review. Can. J. Chem. Eng. 1991, 69, 1036-1060. [CrossRef]

9. Gallucci, F.; Fernandez, E.; Corengia, P.; Annaland, M.V.S. Recent advances on membranes and membrane reactors for hydrogen production. Chem. Eng. Sci. 2013, 92, 40-66. [CrossRef]

10. Shu, J.; Grandjean, B.P.A.; Ghali, E.; Kaliaguine, S. Simultaneous deposition of Pd and Ag on porous stainless steel by electroless plating. J. Membr. Sci. 1993, 77, 181-195. [CrossRef]

11. Uemiya, S.; Kude, Y.; Sugino, K.; Sato, N.; Matsuda, T.; Kikuchi, E. A palladium/porous-glass composite membrane for hydrogen separation. Chem. Lett. 1988, 10, 1687-1690. [CrossRef]

12. Jayaraman, V.; Lin, Y.S.; Pakala, M.; Lin, R.Y. Fabrication of ultrathin metallic membranes on ceramic supports by sputter deposition. J. Membr. Sci. 1995, 99, 89-100. [CrossRef]

13. Xomeritakis, G.; Lin, Y.S. CVD synthesis and gas permeation properties of thin palladium/alumina membranes. AIChE J. 1998, 44, 174-183. [CrossRef]

14. Chen, S.C.; Tu, G.C.; Hung, C.C.Y.; Huang, C.A.; Rei, M.H. Preparation of palladium membrane by electroplating on AISI 316L porous stainless steel supports and its use for methanol steam reformer. J. Membr. Sci. 2008, 314, 5-14. [CrossRef]

15. Mardilovich, P.P.; She, Y.; Ma, Y.H.; Rei, M.H. Defect-free palladium membranes on porous stainless-steel support. AlChE J. 1998, 44, 310-322. [CrossRef]

16. Chi, Y.H.; Uan, J.Y.; Lin, M.C.; Lin, Y.L.; Huang, J.H. Preparation of a novel Pd/layered double hydroxide composite membrane for hydrogen filtration and characterization by thermal cycling. Int. J. Hydrogen Energy 2013, 38, 13734-13741. [CrossRef]

17. Chi, Y.H.; Lin, J.J.; Lin, Y.L.; Yang, C.C.; Huang, J.H. Influence of the rotation rate of porous stainless steel tubes on electroless palladium deposition. J. Membr. Sci. 2015, 475, 259-265. [CrossRef]

18. Martinez-Diaz, D.; Martínez del Monte, D.; García-Rojas, E.; Alique, D.; Calles, J.A.; Sanz, R. Comprehensive permeation analysis and mechanical resistance of electroless pore-plated Pd-membranes with ordered mesoporous ceria as intermediate layer. Sep. Purif. Technol. 2021, 258, 118066. [CrossRef]

19. Martinez-Diaz, D.; Sanz, R.; Carrero, A.; Calles, J.A.; Alique, D. Effective $\mathrm{H}_{2}$ separation through electroless pore-plated Pd membranes containing graphite lead barriers. Membranes 2020, 10, 410. [CrossRef]

20. Zhang, D.; Zhao, J.; Yang, P.; Chen, Y.; Fan, Y. Preparation of high stability Pd/Ceramic/Ti-Al alloy composite membranes by electroless plating. Front. Chem. 2020, 8, 202. [CrossRef]

21. Volpe, M.; Inguanta, R.; Piazza, S.; Sunseri, C. Optimized bath for electroless deposition of palladium on amorphous alumina membranes. Surf. Coat. Technol. 2006, 200, 5800-5806. [CrossRef]

22. Roa, F.; Way, J.D. The effect of air exposure on palladium-copper composite membranes. Appl. Surf. Sci. 2005, 240, 85-104. [CrossRef] 
23. Orakwe, I.; Shehu, I.; Gobina, E. Preparation and characterization of palladium ceramic alumina membrane for hydrogen permeation. Int. J. Hydrogen Energy 2019, 44, 9914-9921. [CrossRef]

24. Gade, S.K.; Thoen, P.M.; Way, J.D. Unsupported palladium alloy foil membranes fabricated by electroless plating. J. Membr. Sci. 2008, 316, 112-118. [CrossRef]

25. Ryi, S.K.; Xu, N.; Li, A.W.; Lim, C.J.; Grace, J.R. Electroless Pd membrane deposition on alumina modified porous Hastelloy substrate with EDTA-free bath. Int. J. Hydrogen Energy 2010, 35, 2328-2335. [CrossRef]

26. Thoen, P.M.; Roa, F.; Way, J.D. High flux palladium-copper composite membranes for hydrogen separations. Desalination 2006, 193, 224-229. [CrossRef]

27. Mardilovich, I.P.; Engwall, E.; Ma, Y.H. Dependence of hydrogen flux on the pore size and plating surface topology of asymmetric Pd-porous stainless steel membranes. Desalination 2002, 144, 85-89. [CrossRef]

28. Yeung, K.L.; Christiansen, S.C.; Varma, A. Palladium composite membranes by electroless plating technique Relationships between plating kinetics, film microstructure and membrane performance. J. Membr. Sci. 1999, 159, 107-122. [CrossRef]

29. Felix, E.M.; Muench, F.; Ensinger, W. Green plating of high aspect ratio gold nanotubes and their morphology-dependent performance in enzyme-free peroxide sensing. RSC Adv. 2014, 4, 24504-24510. [CrossRef] 